\title{
SMALL BUSINESS IN LATVIA - TRENDS AND FACTS IN FIVE YEARS
}

\author{
Iluta Riekstina ${ }^{1}$, Mg. Public Administration, Rosita Zvirgzdina ${ }^{2}$, Dr.oec, prof.
}

1,2Turiba University

\begin{abstract}
At the beginning of 2019, 141,812 active entities were registered in the Commercial Register maintained by the Register of Enterprises, the largest number of which are Limited liability companies $(129,423)$, Individual Merchants $(10,282)$ and other forms of business are much less represented. Based on the European Commission (EC) Regulation No. 800/2008, Annex 1, all enterprises are divided into groups - small (micro), small and medium enterprises (SMEs) and large enterprises. Based on official data, around $99 \%$ would be in the category of small and medium-sized enterprises (SMEs). The breakdown of economically active SMEs by the Ministry of Economics is (Ministry of Economics, 2016): micro enterprises - $90 \%$, small enterprises - $9 \%$, medium enterprises - $1 \%$. The European Commission considers SMEs and entrepreneurship as key to ensuring economic growth, innovation, job creation, and social integration in the European Union. During the last five years, there have been significant changes in the principles, conditions and microenterprise regulations of microentrepreneurs. There are still many entrepreneurs in Latvia who are active and who employ a large number of all Latvian employees and companies contribute to the Latvian economy. Further analysis and research is based on the data of the last five years - regional ownership of enterprises, fields of activity, dynamics of revenue change, dynamics of the number of employees, age of enterprises. The aim of the research is to carry out the analysis of facts and trends observed in the activity of micro and small enterprises (MSe) in the last five years in Latvia. The research is based on official business data from several sources - the Register of Enterprises of the Republic of Latvia, the Ministry of Economics, official reuser of the data of the Register of Enterprises Ltd "Lursoft", Central Statistical Bureau.
\end{abstract}

Key words: small business, microenterprises, economic activity 2013-2017 Latvia, significance of small and micro businesses.

JEL code: D43, E23, E24, M20, M21.

\section{Introduction}

In the context of national macroeconomic, companies are one of four economic agents (Gods, 2002), they build a model of macroeconomic flows. In its turn, the annual report prepared by the merchant is an indication of its economic activity or intention to be economically active in the future. Starting from year 2010, the number of companies submitting annual reports in Latvia exceeds 100 thousand. Although the number of registered subjects is higher, 141812 active subjects have been registered in the Commercial Register at the beginning of 2019 by the Register of Enterprises. The number of submitted annual reports indicates that the decisions taken by the state institutions - the State Revenue Service and the Register of Enterprises regarding the liquidation of forced subjects have been correct. For example, in 2016, the Register of Enterprises excluded 8560 inactive companies from the register, and in 2015 there were 2165 inactive companies excluded from register. Thus, leaving registered entities whose decision is based on doing business. Limited liability company is the most popular form of business in Latvia and as of January 2019 it is 129 423, which is $91.26 \%$ of all registered entities in the Commercial Register. The last finance reporting period for which data are reported is 2017, and that is $86.07 \%$ of all 130256 annual reports are made up of subjects - 110785 micro enterprises and 1330 small enterprises. Small and micro enterprises play an important role in the Latvian economy. Significance is based on the large number of companies in Latvia.

The geographical concentration of Latvian residents in city Riga and the neighbourhood of Riga has been the basis for the majority of micro and small enterprises concentrated in the capital city of

\footnotetext{
${ }^{1}$ Iluta Riekstina, 0037129276170 , iluta.riekstina@gmail.com

2 Rosita Zvirgzdina, 0037126408253, rosita@turiba.Iv
} 
Riga, too. However, their role in the regions is increasing, allowing the population to develop their business, generate income for themselves and their families, create new jobs in the regions and employ more and more people. It is micro and small enterprises that help to ensure the existence of the Latvian economy. First and foremost, they create competition in the internal market and thus contribute to lower prices and the quality of products and services. Secondly, it is micro-enterprises and small businesses that are involved in supply chains and provide part of the production processes and raw materials of medium and large enterprises by supplying them with goods and/or services. Third, micro and small businesses are better able to adapt to different changes in consumer demand. And thanks to small and micro businesses, the middle class of the population and the improvement of the quality of life are ensured.

The aim of the research is to create a profile of micro and small enterprises in Latvia by analysing several parameters - number, financial turnover, economic activities and regional affiliation.

The research tasks are:

- categorize companies according to the set parameters;

- analyse the dynamics of the number of micro and small enterprises for five years (2013-2017);

- analysis of the regional breakdown and scope of economic activities (NACE);

- analysis of trends in turnover and number of employees in micro and small enterprises and research of trends for the last five years;

- to create the economically active micro and small enterprises summary, which provides impact on the Latvian economy.

The author puts forward the hypothesis that the quantitative number of micro and small enterprises, employment capacity, financial indicators have stabilized and do not show significant changes in the last five years. Thus, it is necessary to continue the study or research on the key influences of micro and small businesses.

This quantitative study is based on primary data sources - official variable data for micro and small enterprises in Latvia. The study will look at data and trends for the last five years, analysing data for 2013-2017. According to Article no.5 of the Law "Law on the Annual Financial Statements and Consolidated Financial Statements", all companies are divided into micro, small, medium and large. The criteria set out in the law are different from the ones set out in Annex 1 to the European Commission (EC) Regulation No. 800/2008. The study was carried out according to the criteria set out in the Regulation for the classification of enterprises. One of the factors is the number of employees. Microenterprises include companies employing less than 10 employees and those employing small businesses employing between 11 and 49 employees. Turnover for microenterprises should not exceed EUR 2 million and for small businesses EUR 10 million. Balance sheet total, net turnover and average number of employees are indicators that merge merchants into a specific category - micro or small business.

The following research methods have been used for the research: quantitative data research approach, analytical study comparing data for five years and graphical method - visualization and analysis of visual information.

\section{Research results and discussion}

The analysis of the demographic situation of entrepreneurship is the basis for forecasting the duration of business creation, liquidation and the existence of companies in order to assess the impact on the economic growth and employment strategy indicators of a particular country. 
According to the OECD (Organization for Economic Co-operation and Development) indicators, business demographic indicators are related to the registration of new companies, liquidation of enterprises, employment. The 2017 study on the establishment of new businesses shows that an increasing number of people who have decided to start their own business are involved in business. Likewise, Lursoft's study (Lursoft, 2018) shows that of all participants who registered a new company in 2017, in $61.10 \%$ of cases the name of the person has not been found in the lists of other companies registered in Latvia. During the year, the number of such persons has increased, as in 2016 the share of participants who registered the first company was $55.79 \%$ (Lursoft, 2018). The dynamics of the number of small and micro-companies that have submitted annual reports in accordance with the current laws and regulations in the author's research in the last five years show minor changes. The impact of small business on the national economy has recently been studied by researchers in Ukraine. The study concludes that small business could not provide a cumulative effect on productivity growth, which was observed in the sector of large and medium-sized enterprises, and vice versa - the dynamics of labour productivity in small business worsened the average for economy performance and has caused a decline in the real added value at $5.2 \%$ of the base year (Kalchenko, Trusova, Hrybova, Serbii, 2018).

\section{Regional breakdown of enterprises}

The territory of Latvia is divided into five regions consisting of counties and cities. In 2009, following the Administrative territorial reform of Latvia completed in the country, Latvia has the following regions: Riga, Kurzeme, Vidzeme, Zemgale and Latgale. There is a very large concentration of business and population in Riga region in Latvia. The Riga region is located in the central part of Latvia and its centre is the capital of Latvia, Riga, which is internationally recognized as one of the most important metropolises in the Baltic Sea region. At the end of 2017, there were 704476 inhabitants in Riga, which is $36.42 \%$ of all 1,934 million inhabitants of Latvia. The map (figure no.1) shows that regions are similar in terms of area. Paul Bunt, Emeritus Professor of Entrepreneurship at the University of Bedfordshire Business School, UK, has said that "a small business is based on a man with his desire to work with his goals" (Bunt, 2016). It should also be taken into account that "the whole business is based on a person - as a client, as an employee" (Bunt, 2016), every business needs people, needs them near and on a regular basis.

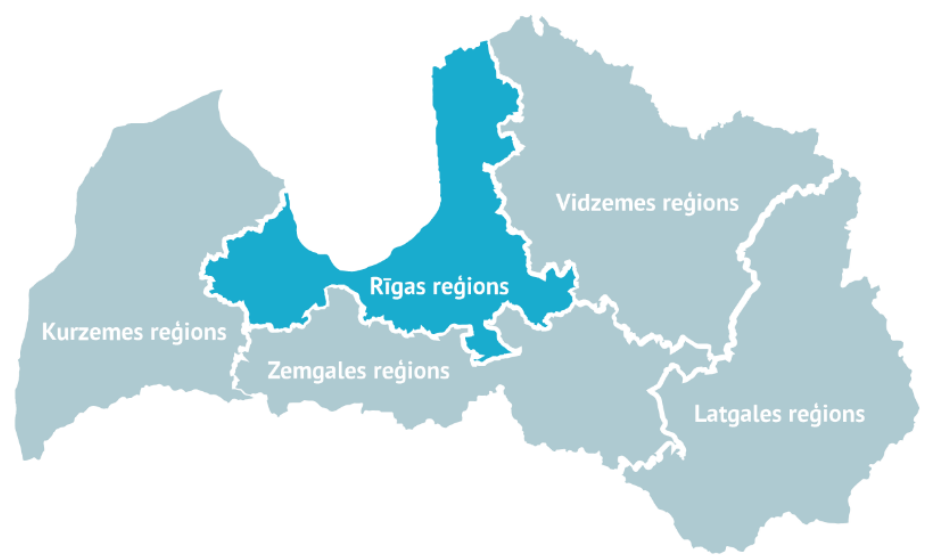

Fig. 1. Regions of Latvia

The regional division of micro and small businesses shows (Figure 2) that there has been No significant change in any of the regions over the last five years. The largest number of micro and small companies that have submitted annual reports is in Riga region. In terms of number, it has 
reached around 80,000 companies throughout the year, averaging $72.3 \%$ of all micro and small businesses in Latvia. In other regions, the number of companies does not exceed $8 \%$ of all micro and small enterprises in Latvia. Which shows very high concentration of micro and small companies in Riga and Pieriga. The average number of companies in the Kurzeme region is 8773 , at the end of 2017 it is $7.89 \%$ of all micro and small enterprises. In Latgale and Vidzeme, a very small number of changes in the number of 5 years, which fall within $0.2 \%$. And only in Zemgale, there is an increase in the number of companies, which in the five-year period represents an increase of $0.3 \%$ at the end of 2017, 8149 companies have been registered in Zemgale region.

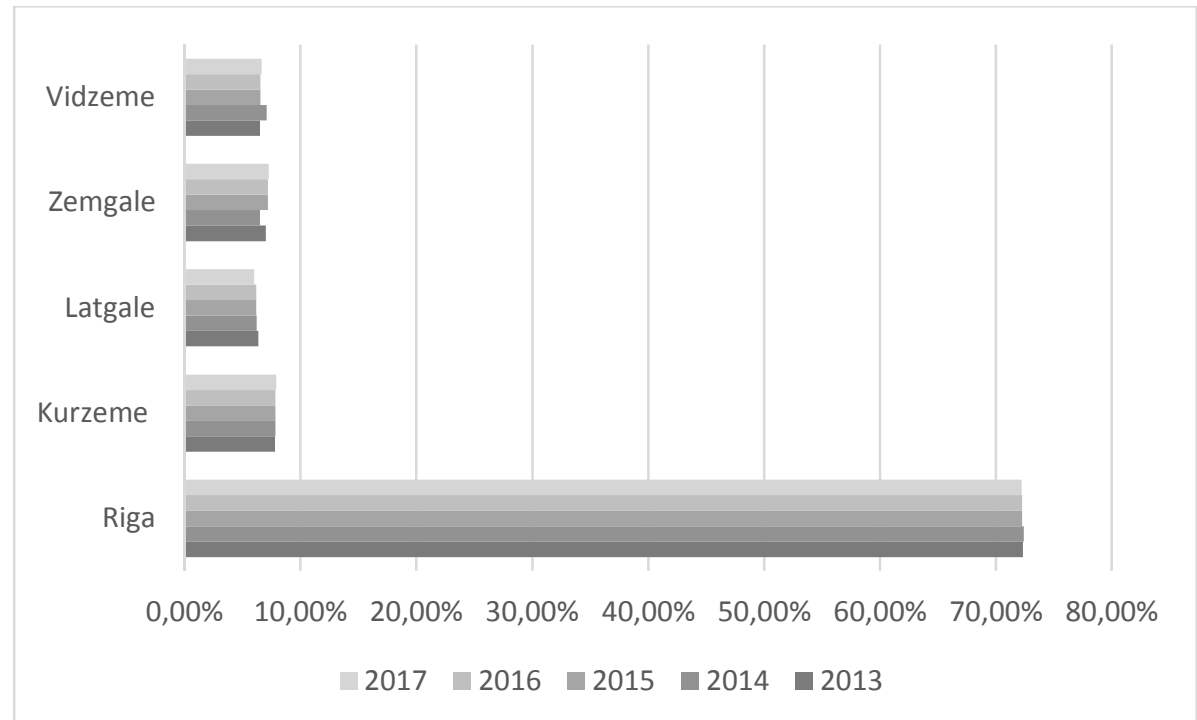

Fig. 2. Micro and small enterprises regional breakdown, 2013-2017, \% from all MSe

Micro to small businesses are very important for the Latvian economy in quantitative terms. Between 2013 and 2017, these companies account for an average of $86.74 \%$ of the total number of annual reporting companies. The calculation is based on the data analysed below.

Table 1

Annual Financial Statements (AFS) count

\begin{tabular}{|l|l|c|c|c|c|c|}
\hline No & & $\mathbf{2 0 1 3}$ & $\mathbf{2 0 1 4}$ & $\mathbf{2 0 1 5}$ & $\mathbf{2 0 1 6}$ & $\mathbf{2 0 1 7}$ \\
\hline $\mathbf{1 .}$ & Total number of AFS & 123846 & 128646 & 130935 & 131273 & 130256 \\
\hline $\mathbf{2 .}$ & $\begin{array}{l}\text { Micro, small enterprises (MSE) } \\
\text { AFS }\end{array}$ & 108401 & 112220 & 113328 & 113332 & 112117 \\
\hline 3. & \% MSE AFS from all & $87.52 \%$ & $87.23 \%$ & $86.55 \%$ & $86.33 \%$ & $86.07 \%$ \\
\hline
\end{tabular}

The study shows that significant changes are not felt even though several activities to support entrepreneurship have been undertaken at national level since 2007. The first activities were carried out during the planning period 2007-2013. The next support activities are for 2014-2020. planning period. Support activities included the following support activities: investment in the creation or reconstruction of industrial premises, training of employees to promote competitiveness, start-up of business and development of small and small enterprises in specially supported territories. In order to promote business development in the regions, in the begin of 2018, the government supported amendments to the Regional Business Incubator and Creative Industries Incubator Support Program, specifying the conditions for the use of co-operative premises in business incubators, the organization of business promotion activities, and the publicity of project information. The results of this activity can only be evaluated from 2020 onwards. On the basis of the data, it has to be concluded that micro 
and small enterprises have not experienced such state support within the last five years that would have reached the set goal - development of regional business.

\section{Business activities (NACE 2.0)}

By NACE Rev. 2, the scope of all enterprises is divided into 21 top-level headings, marked by letters. Micro and small businesses operate for 19 of them. Considering that micro and small enterprises make up the majority of the total number of Latvian companies, it is only natural that the most popular business sector among these companies is the same as the most popular business area in Latvia.

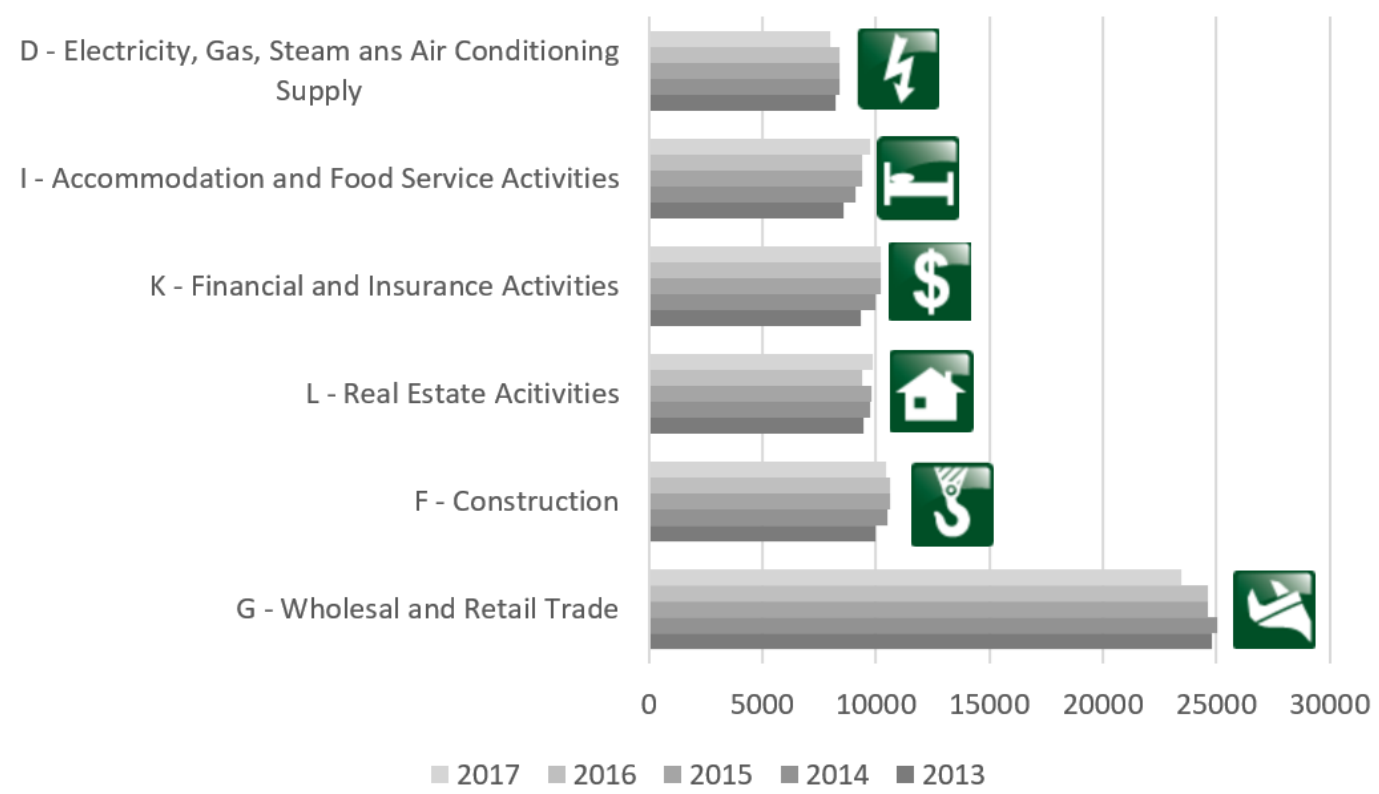

Fig. 3. TOP 6 MSe economic activities for five years

In the study, the author analysed all 19 areas of activity by NACE 2.0 classification. The data analysed show that almost one fifth or $20.9 \%$ of all micro and small enterprises in Latvia associate their core business with retail or wholesale (except cars and motorcycles). Other areas of activity are TOP 6. Each of them operates from $7 \%$ to $9 \%$ of all micro and small businesses. TOP 6 is the second most popular field of activity - construction (10426 companies on average), followed by real estate activities (9657 companies). Among the most widespread industries in which Latvian micro and small companies are most likely to operate, accounting and legal services, accommodation and promotion services and activities in the areas of electricity, gas, heat and air conditioning are also mentioned. And this analysis of data also shows a stabilization in the scope and a slight change in their structure over the last five years.

\section{MSe Analysis of Turnover}

European Commission (EC) Regulation No.800/2008 Annex 1 also sets the total turnover or balance sheet total to 2 million EUR and up to 10 million EUR. However, a very large number of micro and small businesses show that their sales revenue (turnover) is 0 and they practically do not participate in the macroeconomic flow. These companies do not participate in economic activity during the period under review (Hofs, 2002). However, the financial report submitted largely indicates the intention of the owners to operate in the future. It should be noted that the breakdown of enterprises is based on the financial data submitted for the previous period. Because it is quite clear that only through cash flow generation can the company be able to employ employees, provide 
production or service. And in this case, it is not even a question of analysing other factors that could cause a crisis in the company (Rurane, 2002). The Table 2 shows the number of micro and small enterprises, which in the period of 2013-2017 had No turnover for the year (turnover was 0 EUR).

Table 2

Companies with turnover 0 EUR

\begin{tabular}{|l|c|c|c|c|c|c|}
\hline No & Indicator & $\mathbf{2 0 1 3}$ & $\mathbf{2 0 1 4}$ & $\mathbf{2 0 1 5}$ & $\mathbf{2 0 1 6}$ & $\mathbf{2 0 1 7}$ \\
\hline 1. & Number of companies (info AFS) & 26443 & 27130 & 26066 & 32429 & 24937 \\
\hline 2. & $\%$ of all companies (info AFS) & $24,4 \%$ & $24,2 \%$ & $23 \%$ & $28,6 \%$ & $22,2 \%$ \\
\hline Average in 5 years (count/ \%) & \multicolumn{3}{|c|}{$27401 / 24,5 \%$} \\
\hline
\end{tabular}

The remaining companies were divided into several turnover groups by the author. The second group from 1 to $12 \mathrm{~K}$ has been selected for analysis. Thus, a micro-enterprise can theoretically provide services with such turnover for one employee approaching the average wage calculated in the country. The third group has a turnover of $12 \mathrm{~K}-50 \mathrm{~K}$, the fourth group $50 \mathrm{~K}-100 \mathrm{~K}$, the fifth $100 \mathrm{~K}$ $-2 M$, the sixth $2 M-10 M$, the seventh - more than 10M EUR.
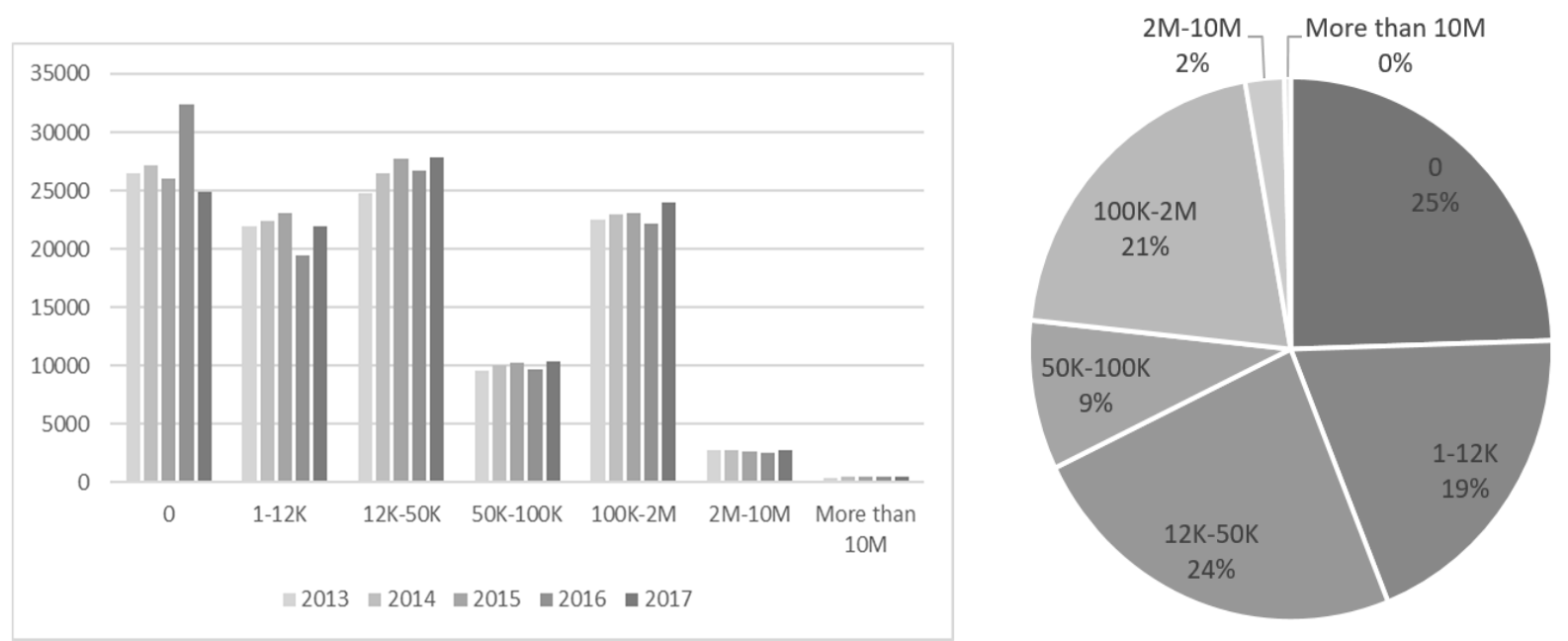

Fig. 4 and 5 MSe turnover breakdown in 2013-2017

The analysis shows that in the last five years in Latvia stabilization of the turnover of enterprises has been observed. A significant increase (compared to $19.62 \%$ in 2015 compared to 2016) is seen in the number of companies with a turnover of 0 EUR. In 2017, however, it returns to previous levels. This can be explained by changes in the law on micron tax payers, the registration of these companies, but not the initiation of active activities. Decisions taken by state institutions (State Revenue Service and Register of Enterprises) regarding the forced liquidation of subjects. While new businesses are becoming more cautious, the number of liquidated companies has continued to grow rapidly in 2017 , rising by $34.78 \%$ over the year to 16479 . It should be noted that the number of companies liquidated last year has been the highest in the last 26 years. Returning to a normal state is a sign of improving the business environment for micro and small businesses by eliminating "empty" companies.

\section{Employment in MSe}

Employment is a fundamental economic problem that leads to widespread social resonance (Gods U., 2002). By definition, micro and small businesses employ between 1 and 49 employees. The research has carried out a study on the average number of employees in the company and changes in the number of employees in the five-year period. Analysis of the number of employed in Latvia 
from 15-74 years for the period 2013-2017. The year 2010 shows a direct correlation with employees in micro and small enterprises.

Table 3

Dynamics of the number of employees

\begin{tabular}{|l|l|c|c|c|c|c|}
\hline No & \multicolumn{1}{|c|}{ Indicator } & $\mathbf{2 0 1 3}$ & $\mathbf{2 0 1 4}$ & $\mathbf{2 0 1 5}$ & $\mathbf{2 0 1 6}$ & $\mathbf{2 0 1 7}$ \\
\hline 1. & Employed aged 15-74 in Latvia & 894000 & 882800 & 896100 & 893300 & 894800 \\
\hline 2. & Employed in MSE & 466283 & 478396 & 481060 & 438174 & 454532 \\
\hline & \multicolumn{1}{|c}{ Ratio $\%$} & $52 \%$ & $54 \%$ & $53 \%$ & $49 \%$ & $51 \%$ \\
\hline
\end{tabular}

On the basis of data of the Central Statistical Bureau of Latvia and the analysis of the submitted annual report, the author concludes that there is stability in employment as well as No significant changes. In all years, around half of the employees are employed in micro and small businesses. This statement might change slightly after a more detailed analysis, as quantitative data in the company's financial statements have been taken into account for the analysis. The number of employees does not exclude the same employee in several companies.

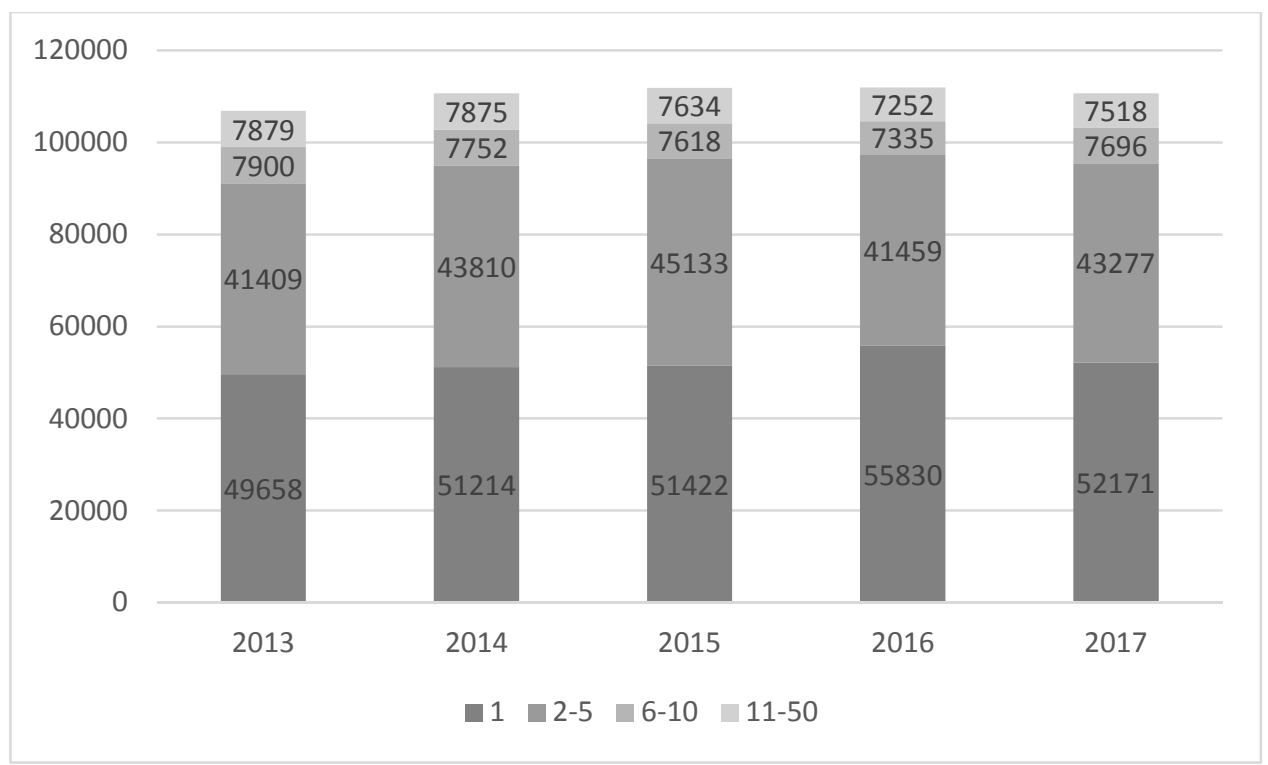

Fig. 6. Number of employees in MSe

The author has divided all the micro and small businesses into groups according to indicator that shows how much the company employs employees. Figure 6 shows that there are most micro and small businesses that employ 1 employee. In 2016, the number of such companies is the highest, but according to the acquisitions by public authorities, this number has decreased in 2017 . There are still a lot of companies employing 2 to 5 employees, so the author argues that the support of micro and small businesses is the most indispensable for these companies, and this will also affect national employment.

\section{Conclusions, proposals, recommendations}

1) The study confirms the hypothesis that the number of micro and small enterprises, the employment capacity, the financial indicators have stabilized and do not show significant changes over the last five years. Thus, the author has a reason to conduct a study or research on the key influences of micro and small businesses (e.g. process management).

2) The study allows us to conclude that without changing the rapidly regulating norms, there are about 60 thousand economic assets in Latvia (with a turnover exceeding EUR 12 000). 
3) There is a very high concentration in Riga and Pieriga, where there are over $70 \%$ of all micro and small enterprises. In other regions, the number of companies does not exceed $8 \%$ in each region. This is dangerous for regional development.

4) In the study, the author analysed the areas of activity in which businesses operate MSe. As a result, the author has selected TOP 6 areas of activity for micro and small enterprises in Latvia that do not show significant changes over the last five years.

5) All MSe can be divided into 6 parts according to their turnover. There is a tendency to have a large number of companies with No financial turnover (around $27 \mathrm{~K}$ companies on average) throughout the years. Companies with a turnover below $12 \mathrm{~K}$ EUR are about $21 \mathrm{~K}$. The author concludes that only about 60 thousand companies give a financial contribution to the Latvian economy.

6) MSe mostly employ one person, who is usually the owner and the member of the board too. But there are also many companies employing between 2 and 5 employees (around 43K micro and small businesses).

7) In the study, micro and small enterprises have shown stability over the analysed criteria over the last 5 years - number dynamics, regional breakdown, financial turnover and number of employees.

\section{Bibliography}

1. Bunt, P. (2016). Entrepreneurship and small business Start-up, growth and maturity, 2016, No 1, pp.42, 198.

2. Caune, J., Dzenns, A. (2009). Startegiska vadisana, 2016, No 3, pp.69, 80.

3. Gods, U. (2002). Makroekonomika, 2002, pp.17.

4. Hofs, K.G. (2002). Biznesa ekonomika, 2002, pp. 24, pp. 275.

5. Kalchenko, S., Trusova, N., Hrybova, D., \& Serhii, B. (2018). The small and large business interaction within national economy's gross added value reproduction in Ukraine. Oeconomia Copernicana, 9(3), 403-417. doi: 10.24136/oc.2018.020

6. Kroplijs, A., Rascevska M., (2010). Kvalitativas petniecibas metodes socialajas zinatnes, pp.20.

7. Rurane, M. (2002). Uznemejdarbibas organziacija un planosana, pp.130, pp.321.

8. Law on the Annual Financial Statements and Consolidated Financial Statements. Gada parskatu un konsolideto gada parskatu likums. Latvijas Vestnesis, 222 (5540), 12.11.2015. Retrieved: https://likumi.Iv/ta/id/277779-gada-parskatu-un-konsolideto-gada-parskatu-likums Access:12.11.2015.

9. Business Environment Review by Ministry of Economics (2015). Retrieved: https://www.em.gov.Iv/lv/nozares_politika/nacionala_industriala_politika/uznemejdarbibas_vide_/. Access: 13.06.2017.

10. A description of the business incubator support program for business promotion in the regions has been specified (2018). Retrieved: http://www.liaa.gov.lv/lv/aktualitates/uznemejdarbibas-sekmesanai-regionosprecizeta-biznesa-inkubatoru-atbalsta-programma. Access: 18.01.2018.

11. Employment and unemployment Central Statistical Bureau of Latvia publication (2018). Retrieved: https://www.csb.gov.Iv/lv/statistika/statistikas-temas/socialie-procesi/nodarbinatiba. Access: 22.02.2019.

12. Average monthly and median wages and salaries (2013-2017). Retrieved: http://data1.csb.gov.Iv/pxweb/Iv/sociala/sociala_dsamaksa_ikgad/DSG010.px/?rxid=f15af91d-605e4b12-b3e3-4e30ce2715ca Access: data available in an online database starting with 1990

13. Business demography indicators by kind of principal activity by statistical regions (2013-2017). Retrieved: https://data1.csb.gov.Iv/pxweb/lv/uzn/uzn_uzndarb/SBG070.px Access: data available in an online database starting with 2007

14. Lursoft study: Micro and small enterprises play an increasingly important role in the Latvian economy (2013). Retrieved: http://blog.lursoft.Iv/2013/05/30/lursoft-petijums-mikro-un-mazie-uznemumi-latvijasekonomika-ienem-aizvien-nozimigaku-lomu/ Access: 30.05.2013.

15. Statistics Number of annual reports recorded (2019). Retrieved: https://www.lursoft.Iv/lursoft_statistika/?\&id=62. Access: data available in an online database starting with 1997 